\title{
実験データに基づく音響感度解析法の 開発とその適用*
}

\author{
大久保信行** 増田克已***
}

Development of Acoustic Sensitivity Analysis Based on Experimental Data and its Applications

Nobuyuki Oкuвo and Katsumi Masuda

\begin{abstract}
The experimental modal analysis is widely utilized in dynamic design of machines to meet the requirement for less vibration and noise, and further the sensitivity analysis is newly adopted to find the appropriate points to reduce the vibration due to structural modification for better dynamics. On the contrary, concerning about the noise induced by the vibration, the present analysis consists of two steps: after the vibrational sensitivity analysis, the noise may be predicted through coefficient of sound radiation, for instance, which yields rather time consum. ing and inaccuracy. This paper describes the development of a new acoustic sensitivity analysis, which is directly based on the result of acoustic modal analysis when measuring the sound with a microphone against the excitation force. This analysis can provide very useful informations on which parts of the structure should be modified in order to reduce the noise with easy-use and enough accuracy. A simple plate structure and a complex automobile engine are used to confirm the effectiveness of the acoustic sensitivity analysis developed.
\end{abstract}

Key words : acoustic modal analysis, acoustic sensitivity, structural modification

\section{1. はじめに}

最近の機械は単に高性能，高精度のみ追及して設計 されるだけでなく，人間にとってょり快適な状態で稼 動するよう, 具体的には低振動, 低騒音化が重要な観 点となってきている.

このため，振動に関しては実験的なモーダル解析が 広く普及し，さらにはそのデータに基づき，機械のど の部分を構造変更すれば効率よく振動が低下できるか を予測する感度解析が大きな成果をあげている11.

一方, 振動から発生する騒音に関しては, 単に構造 のある点の振動が小さくなれば騒音が低下するという 訳にはいかず，多くの試行錯誤が必要とされている. 解析手法としても, いったん振動に関する感度解析を 行い, 次に予測された振動からどのような騒音が発生 するかを音響放射係数等により計算するため, 複雑な 手順となり，高い予測精度も期待できなかった ${ }^{2)}$.

そこで，本論文では振動から発生する騒音を直接に

* 原稿受付 平成元年 5 月 31 日. 1989 年度精密工学会春 季大会学術講演会 (平成元年 3 月 22 日) にて発表

** 正会員 中央大学理工学部（東京都文京区春日 1-1327）

*** 学生会員 中央大学大学院
測定する音響モーダル解析（構造物に加振力を与兄, その応答としての音环をマイクロホンで計測する）の 実験データに基づき, 構造のどの部分を変更すれば騒 音がどのように変化するかを予測する簡便で，実用的 な音響感度解析法の開発について述べる.

さらに, この解析法を簡単な板構造物, 複雑な自動 車ェンジンブロックに適用した結果についても触れ る.

\section{2. 音響モーダル解析}

本論文で新しく提案する音響感度解析について述べ る前に，その基本となる音響モーダル解析について概 説する.

構造物の $i$ 点を加振した際, 構造物から適当な距離 に扔かれたマイクロホンで計測される音王 $p$ と加振 力 $F_{i}$ との間の周波数応答関数, $H_{i}$ (ここでは音響层 達関数と呼ぶ）は次式のように表せる.

$$
H_{i}(\omega)=\frac{p}{F_{i}}=\frac{\rho \omega^{2}}{2 \pi} \sum_{r=1}^{n}\left\{\frac{\phi_{i r} \psi_{r}}{j \omega-\lambda_{r}}+\frac{\phi_{i r}{ }^{*} \psi_{r}{ }^{*}}{\mathrm{j} \omega-\lambda_{r}{ }^{*}}\right\}
$$

ここで,

$$
\psi_{r}=\sum_{k=1}^{m} \phi_{k r} \Delta S_{k} \exp \frac{\left(-\mathrm{j} x R_{k}\right)}{R_{k}}
$$


ポール: $\lambda_{r}=-\sigma_{r}+j \omega_{r}$

たたし， $\rho$ : 空気密度， $\chi$ : 波数, $\omega_{r}: r$ 次固有角振 動数, $\sigma_{r}: r$ 次減衰係数, $\phi_{i r}: r$ 次振動モードの $i$ 点成分, $\Delta S_{k}$ : 测定点 $k$ の等価面積, $R_{k}$ : 測定点 $k$ からマイクロホンぬでの距離, $n$ : 振動モード総数,

$m$ : 測定点総数, *は共役項を表す.

ここでは，各測定点がその等価面積をもつ独立した 近接音源であるとの仮定に基づいている3).

通常の加振力-変位間の伝達関数では, 式 (1) 中の 分子の項が加振点と応答点の振動モード成分の積に相 当するのに対し，振動モードの加振点成分と全測定点 の音源としての寄与との積となる点が異なる．した がって，ハンマにより構造物の各測定点をたたきまわ る加振点移動による音響モーダル解析の際には, この 音源としての寄与の項は一定であるので，測定された 各音響伝達関数から振動モードも求められることが分 かる.

\section{3. 音響感度解析法}

振動に関しての伝達関数を測定点における質量, 剛 性により偏分することによって感度解析が行えるのと 同様, 音響伝達関数, 式 (1) を以下のように偏分する ことにより音響感度が求まる。

いま, 構造の $i$ 点に加振力が加わる際の騒音が問題 であるとすると，音響伝達関数， $H_{i}$ を測定点 $a$ に抒 ける構造パラメータ， $P_{a}$ (質量あるいは剛性)によ り偏分し，

$$
\begin{aligned}
\frac{\partial H_{i}}{\partial P_{a}}= & -\frac{\rho \omega^{2}}{2 \pi} \sum_{r=1}^{n}\left\{\frac{1}{\mathrm{j} \omega-\lambda_{r}} \frac{\partial Q_{i r}}{\partial P_{a}}+\frac{Q_{i r}}{\left(\mathrm{j} \omega-\lambda_{r}{ }^{*}\right)^{2}} \frac{\partial \lambda_{r}}{\partial P_{\mathrm{a}}}\right. \\
& \left.+\frac{1}{\mathrm{j} \omega-\lambda_{r}{ }^{*}} \frac{\partial Q_{i r}{ }^{*}}{\partial P_{a}}+\frac{Q_{i r}{ }^{*}}{\left(\mathrm{j} \omega-\lambda_{r}\right)^{2}} \frac{\partial \lambda_{r}{ }^{*}}{\partial P_{a}}\right\}
\end{aligned}
$$

ここで，音響レジデュー： $Q_{i r}=\phi_{i r} \psi_{r}$

\section{と求まる。}

さらに, 式 (2) 右辺の中での偏分の項は構造パラ メータとして $a$ 点に拈ける質量 $M_{a}$ を考慮した場合に は,

$$
\left.\begin{array}{rl}
\frac{\partial Q_{i r}}{\partial M_{a}}= & \sum_{k=1}^{m}\left[-2 \lambda_{r} S_{r, i k} \frac{\partial\left[M_{k k}\right]}{\partial M_{a}} S_{r, k i}\right. \\
& -\sum_{l=1}^{n} \frac{\lambda_{r}^{2}}{\lambda_{r}-\lambda_{l}}\left\{S_{r, i k} \frac{\partial\left[M_{k k}\right]}{\partial M_{a}} S_{l, k i}\right. \\
& \left.+S_{l, i k} \frac{\partial\left[M_{k k}\right]}{\partial M_{a}} S_{r, k i}\right\} \\
& -\sum_{l=1}^{n} \frac{\lambda_{r}{ }^{2}}{\lambda_{r}-\lambda_{l}{ }^{*}}\left\{S_{r, i k} \frac{\partial\left[M_{k k}\right]}{\partial M_{a}} S_{l, k i}^{*}\right. \\
& \left.\left.+S_{l, i k}^{*} \frac{\partial\left[M_{k k}\right]}{\partial M_{a}} S_{r, k i}\right\}\right] \Delta S_{k} \exp \frac{\left(-\mathrm{j} \varkappa R_{k}\right)}{R_{k}}
\end{array}\right\}
$$

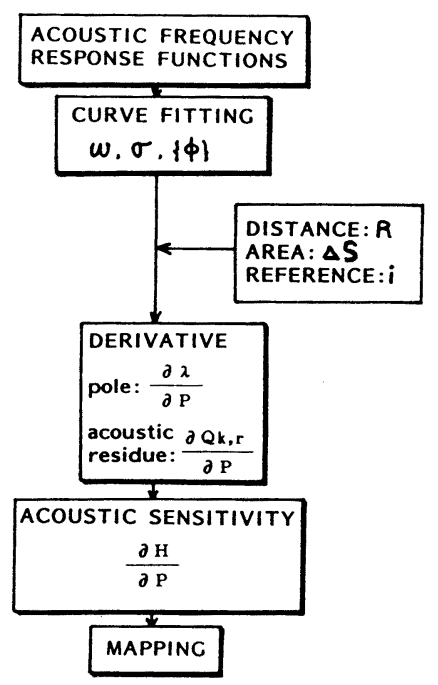

Fig. 1 Flow chart of acoustic sensitivity analysis

$$
\frac{\partial \lambda_{r}}{\partial M_{a}}=-\lambda_{r}{ }^{2} S_{r, i i}{ }^{-1} \sum_{k=1}^{m} S_{r, i k} \frac{\partial\left[M_{k k}\right]}{\partial M_{a}} S_{r, k i}
$$

ここで, 振動レジデュー： $S_{r, i k}=\phi_{i r} \phi_{k r}$

となり, 式中 $\partial\left[M_{k k}\right] / \partial M_{a}$ は,

$$
\begin{aligned}
\frac{\partial\left[M_{k k}\right]}{\partial M_{a}} & =1 \quad(a \neq k) \\
& =0 \quad(a \neq k)
\end{aligned}
$$

この式により，各測定点の質量を変更した際の音響 伝達関数の值の変化が予测でき，ある固有振動数に着 目すれば，構造のどの点の質量を変更すれば大きな騒 音低下が期待できるかがわかる音響マップが作成でき る. 剛性に関しても同様な式が導ける.

以上の手法の手順をまとめてみると図 1 のようにな る.まず, マイクロホンを適切な位置に固定し, 構造 物の各測定点をハンマでたたき，音響伝達関数を測定 する，式（1）をみてわかるよらに，固有振動数，减衰 係数（式中の分母にあたる）に関しては通常のカーブ フィットをそのまま流用すれば求められる.

振動モードに関しては，前述した理由により各音響 伝達関数間の比を計算することにより求められる.

音響感度を計算するためには，まず各測定点に打け る等価面積とマイクロホンとの距離を与え, 次にどの 測定点に加振力が加わった際の騒音を評価するかを指 定する. さらに対象とする固有振動数を与文, その音 響伝達関数のピークに関して各測定点の質量に対する 音響感度が計算され，感度マップとして表現される.

\section{T プレートへの適用}

前述の音響感度解析法を図 2 のような簡単な板構造 


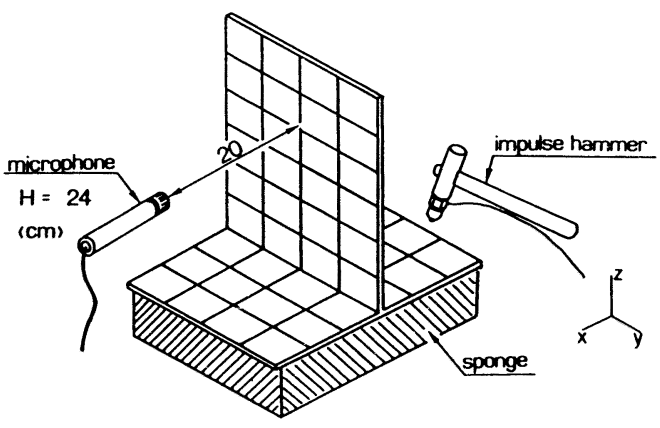

Fig. 2 Measurement set up for T-plate

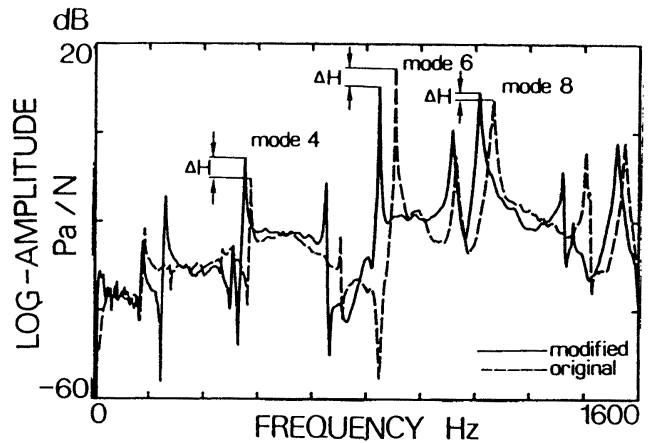

Fig. 3 Typical acoustic frequency response function before and after mass modification

物, T プレート（重さ： $45 \mathrm{~N}$, 厚さ 10 , 幅 260 , 長さ $340 \mathrm{~mm}$ の 2 枚の板を溶接したもの）に適用してみよ 5.ここでは, マイクロホンは各測定点から発生する 音の寄与を適切にとらえるために板の表面から 20 $\mathrm{cm}$, 下面から $24 \mathrm{~cm}$ の高さとした.

まず，各測定点（総数 48）をハンマにより加振し， その際の音響伝達関数を計測した. 図 3 中破線に代表 的な測定結果を示す.な拈，図には示さないが，加速 度計を用いた通常の伝達関数と比較すると, 同一の固 有振動数に招いて音響伝達関数もピークをもち, ハン マによる加振のみが騒音発生原因であることがわかっ ている.

さて，前述したようにこの測定により振動モードも 求められ, 図 4 には通常の加速度計を用いて測定され た振動モード（右段）との比較を示し，振動モード間 の相関を表す MAC 值も 0.9 程度と高く，良好な一致 が得られていることを確認した。

次に質量に対する音響感度解析を行らにあたり，ど の固有振動数に注目すればよいかの目安として図 5 に 示すよらに測定された全音響伝達関数を足し合わせ た.これにより，騒音として問題となるものは，まず モード 4, 次にモード 6,8であることが推測される.
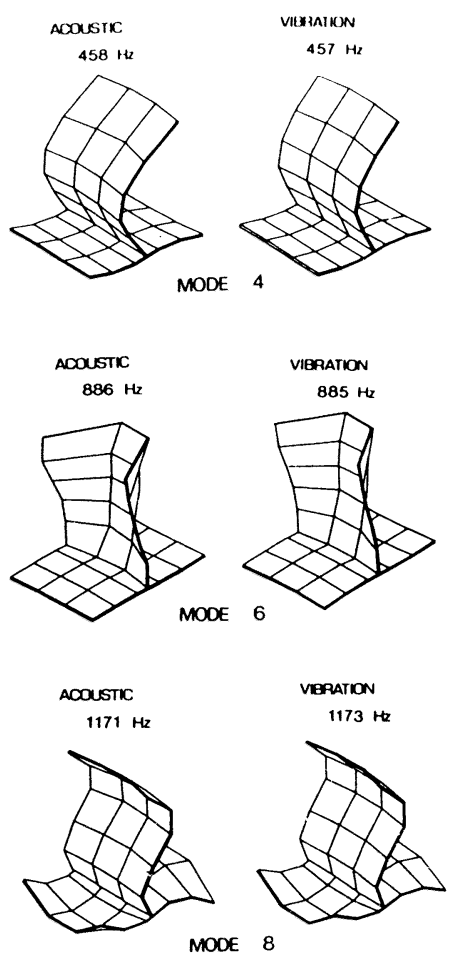

Fig. 4 Measured mode shapes via acoustic modal analysis

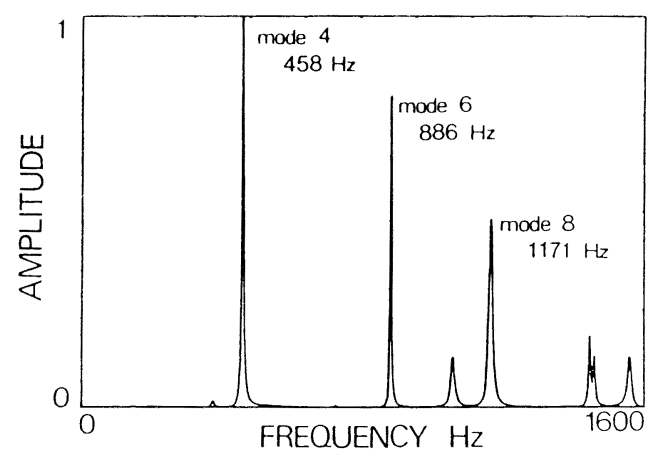

Fig. 5 Cumulative acoustic frequency response function

これらのデータに基づき， Tプレートの 1 か所に 加振力が加わった際, 対象のモードに扔ける音響伝達 関数のピークが，構造の各測定点に打ける単位質量に よりどれだけ変化するかの感度を予測し，表現したも のが図 6 上段の感度マップである.ここで，黒い部分 が感度の高い場所を示し，その箇所の質量変更を行う と大きく音響伝達関数のピーク值が変化することを意 味している.

な扐，この計算の際には各測定点での等価面積およ びマイクロホンとの距離が必要となり, 図 2 中の分割 


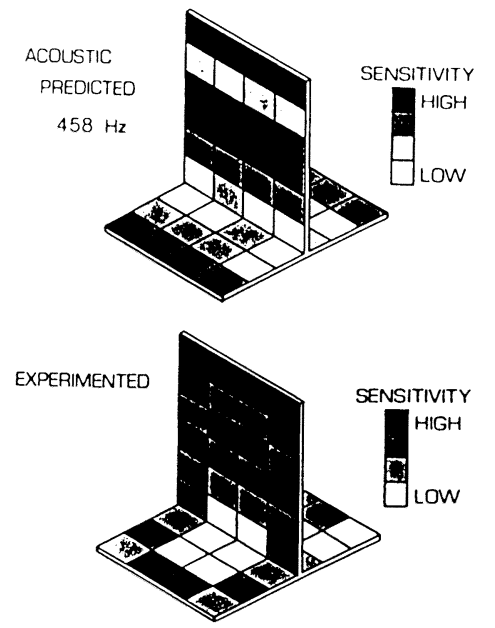

MODE 4
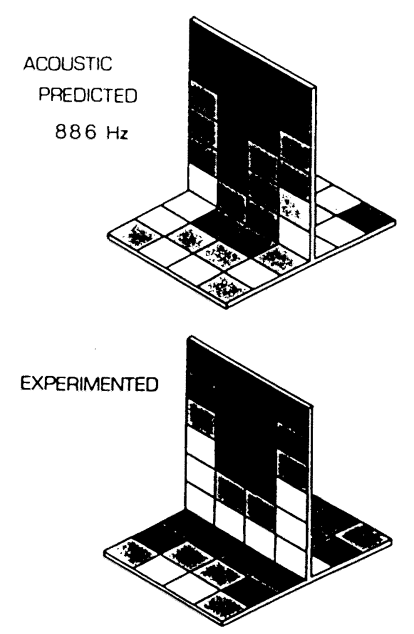

MODE 6

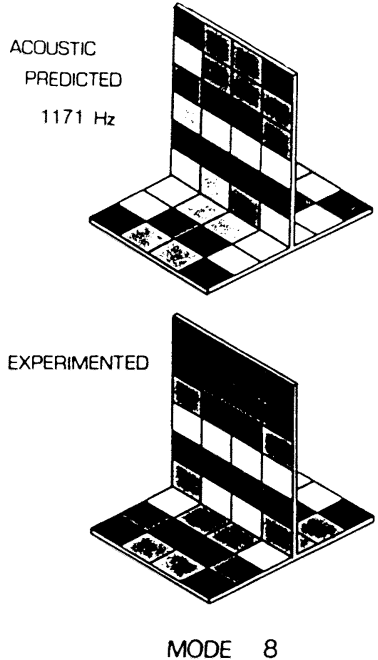

MODE 8

Fig. 6 Predicted and measured acoustic sensitivity map for T-plate
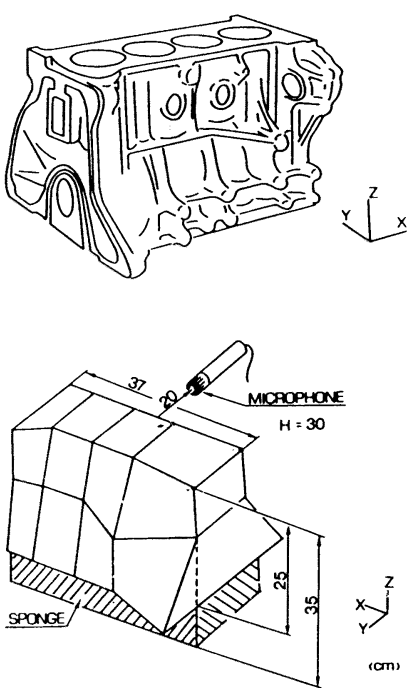

Fig. 7 Measurement set up for 4 cylinder automobile engine block

された 1 板要素の面積および測定点からマイクロホン までの最短距離（板の裏側の水平面からは垂直の板を まわりこむよらに）が用いられた。

一方，この感度予測ゔ正しく行われたかを確認する ために実際に Tプレートに $1.5 \mathrm{~N}$ のおもりを各測定 点に順次取り付け，その際の音響伝達関数の変化を測 定した. 図 3 の実線は垂直板右最上部に打もりを取り 付けた場合の結果である. この図から構造変更前後の 変化量（図中の $\Delta H$ ) がわかり，それらをマップとし て表現したものが図 6 下段である.

この図をみてわかるように，対象とするモード 4,6 および 8 において良い一致がみられ，本論文で提唱寸

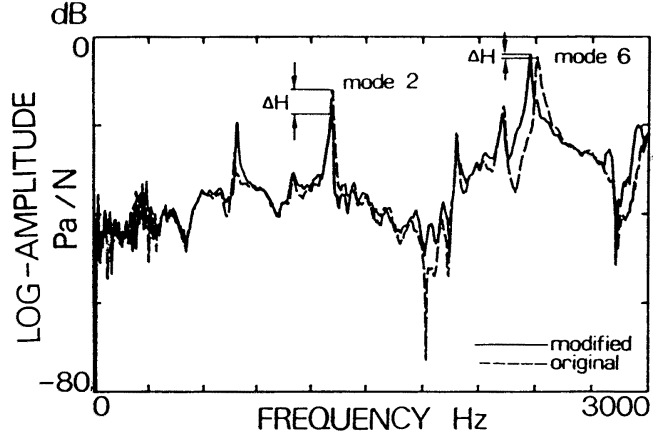

Fig. 8 Typical acoustic frequency response function before and after mass modification

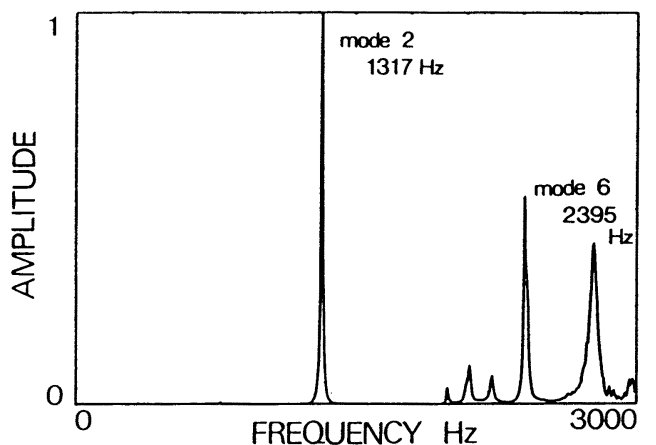

Fig. 9 Cumulative acoustic frequency response function

る音響感度解析法が有効であることがわかった。

$$
\text { 5. エンジンブロックへの適用 }
$$

最後に複雑な構造物として図 7 に示す自動車用 4 気 筒エンジンブロックをとりあげ，音響感度解析法を適 


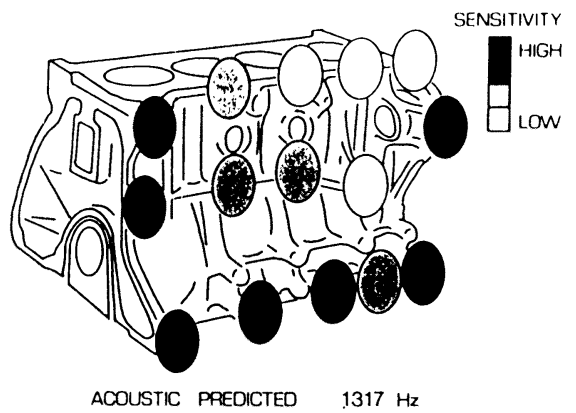

ACOUSTIC PREDICTED $1317 \mathrm{~Hz}$

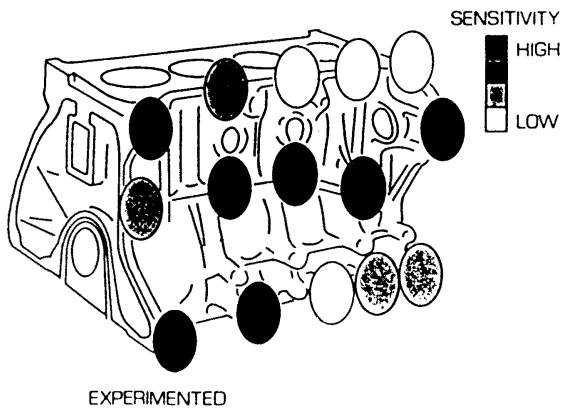

MODE 2

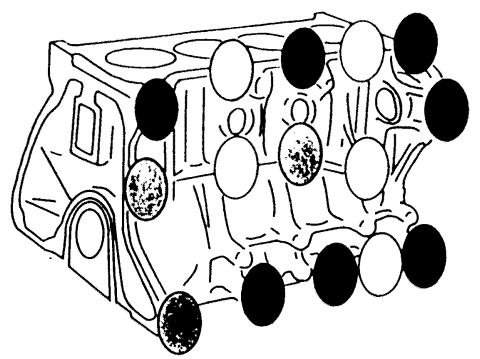

ACOUSTIC PREDICTED $2395 \mathrm{~Hz}$

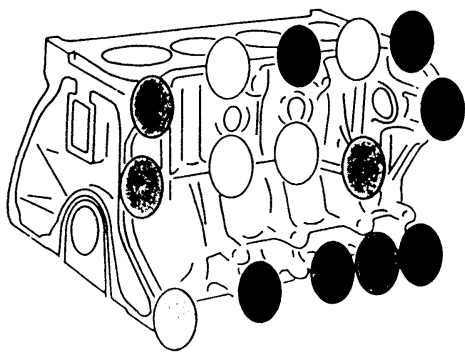

EXPERIMENTED

MODE 6

Fig. 10 Predicted and measured acoustic sensitivity map for engine block

化から読み取り，その値の 大（音響感度が大）小 (小) を図示したものが図 10 下 段である.

音響感度解析による予測 が良好であったことがわか り, 例えばエンジン下部 ミッション取付け部の質量 が変化すると音響伝達関数 のモード 2 のピークは大き く変化する等, 設計に大き く役立つ情報が得られるこ とがわかる。

\section{6. 結 論}

（1）構造物を加振し, その応答として音圧を マイクロホンで検出す ることにより算出され る音響伝達関数を用い た音響モーダル解析に より，振動モードも適
用した．図 8 にはマイクロホンを水平面から $30 \mathrm{~cm}$, ブロック前壁から $20 \mathrm{~cm}$ 離した位置に固定した際の 代表的な音響伝達関数を破線で示す。

次に，測定された全音響后達関数の総和を図 9 に示 す.これによると，モード2（振動モードはェンジン ブロック長手方向の 1 次曲げ）抢よび 6 （長手方向上 部と下部がそれぞれ逆位相の 1 次曲げ）が騒音に大き く寄与するものと考光られる.

そこで，これらのデータに基づき質量感度マップを 計算し，図 10 上段に示す。ただし，各測定点の等価 面積はエンジンブロック側面の概略面積を測定点数で 割った值を用いた.

一方, 実際に $4 \mathrm{~N}$ のおもりを各測定点に順次接着 剤で取り付け，その都度音響伝達関数を測定した。図 8 中の実線は，この怙もりをエンジンブロック側面中 央上部（マイクロホンの正面）に取り付けた際の音響 伝達関数で, 拈もりなしの破線に比べ变化している.

ここで対象のモードに関してのピークの変化量は図中 の $\Delta H$ のように求まる. これと同様な $\Delta H$ の観察を, 各測定点に扣もりを付け替光た際の音響伝達関数の変
切に求まることを確認した.

（2）このようにして求められた音響伝達関数から 直接に, 構造のどの部分を変更（質量あるいは剛 性）すれば音響伝達関数のピークが大きく変化す るかという音響感度を計算する手法を提案した。

（3）この音響感度解析法を簡単な板構造物拉よび 複雑な自動車エンジンブロックに適用し，有効な 手法であることがわかった。

敃わりに，本研究にご協力頂いた鈴木自動車工業 （株に謝意を表します。

\section{参 考 文 献}

1）大久保信行，中島睦夫：センシティビティアナリシスを 用いた機械構造物の動特性改善に関する研究，精密工学 会誌, 52, 7 (1986) 1258.

2) D. K. Young \& M. W. Tretheway: Surface Intensity Measurements for the Prediction of Sound Radiation from Structual Modifications, Proc. 3rd IMAC, (1985) 645 .

3）汇嶋聞夫：アコースティックモーダルアナリシス, 小松 技報, 30, 2(1984) XV 1 . 